\title{
Legal Protection of Endangered Languages IN INDIA WITH REFERENCE TO MEGHALAYA
}

\author{
Dr. Arun Kumar Singh \\ Department of Law, NEHU, Shillong
}

\begin{abstract}
As for as India is concerned many Indian languages have become threatened and even endangered because of globalization. In India, English is thriving and is used widely by the young generation, and this is one of the reasons leading to the extinction of native or regional languages. Today Hindi is also expanding and because of this many regional languages will become extinct. In the State of Meghalaya there are three basic tribes known as Khasi, Garo and Jayantia. They speak either Khasi, or Garo, but their dialects differ. Even the Khasis who are living in East Khasi Hills, especially in Shillong have different dialects as compared to the other Khasis. These languages are used by many but they do not have their own scripts. That is why these languages were not placed in the Eighth Schedule of the Constitution of India. A speaker of any language which is not in the Eighth Schedule, cannot be awarded the Jnanpith Award and furthermore their languages cannot be the medium of the UPSC. Article 29 of the Constitution of India mandates that no discrimination would be done on the ground of religion, race, caste or language and Article 30 mandates that all minorities, whether based on religion or language, shall have the right to establish and administer educational institutions of their choice. In addition, the Legislature of a State may by law adopt any of the languages to use in the state. Article 350 B of the Constitution says that there shall be a Special Officer for linguistic minorities and he/she has to be appointed by the President. It shall be the duty of this Officer to investigate all matters relating to the safeguards provided for linguistic minorities under the Constitution and report to the President upon those matters. Protection of the regional languages has been provided in the Constitution and it is the duty of the educational institutions to provide basic education to the children in their own vernacular languages should they want to be educated in their vernacular language.
\end{abstract}

Key words: Languages, Meghalaya, Constitution of India, Linguistic Minorities, Protection.

\section{INTRODUCTION}

Globalization is a phenomenon which has caused the world to shrink and therefore use of many languages and dialect have also reduced to a large extent due to which many languages have become endangered and Indian languages are no exception to it. Certain Indian languages are endangered and some of them are on the verge of extinction. Certain dialects and tribal languages which are generally unwritten or undocumented are disappearing. Studies to preserve these languages are futile unless legal protection is available.

Considering this backdrop, this paper aims to discuss the laws relating to protection of endangered languages with a special focus on State of Meghalaya in India. For this discussion both International as well as National Provision have been highlighted. The role of judiciary regarding protection and promotion of endangered languages has also been discussed. The methodology that has been adopted is doctrinal and is based on primary and secondary sources.

\section{Classification of Endangered Language}

United Nations Educational, Scientific and Cultural Organization (UNESCO) in 2010 classified endangered languages into various categories as follows:

1. Vulnerable.

2. Definitely endangered.

3. Severely endangered.

4. Critically endangered; and

5. Extinct

As per the UNESCO Report of 2010, about 197 languages are endangered, out of which 81 are vulnerable, 63 are definitely endangered, 06 severely endangered, 42 critically endangered and 05 are extinct languages.

The vulnerable languages are those which is spoken by children but is restricted to the home domain only. Definitely endangered are languages which children no longer learn as 


\section{Yinternational Research Journal}

p-ISSN 2202-2821 e-ISSN 1839-6518 (Australian ISSN Agency)

the mother tongue. It includes various dialects which are not spoken in the home. Severely endangered languages are those which are spoken by grandparents or older generation and is understood by the parent generation, but they do not speak it to their children and among themselves. The critically endangered languages are those which are spoken by grandparents while they were young but are spoken partially and infrequently by them and is not understood by their children and grandchildren. The extinct languages are those which have no speakers, and no one remember the language.

\section{Endangered Languages and Legal Protection}

\section{A. International Provisions}

As far as legal protection of endangered languages is concerned there is no provision which directly protects the endangered languages. However, some attempts have been done at the International level to protect endangered languages by protecting the interest of linguistic minorities. Article 27 of the International Covenant on Civil and Political Rights, 1966 which came into force in 1976 protects the interest of linguistic minorities by stating that they will not be denied the use of their own culture, profess and practice their own religion and use their own languages. Inspired by these provision United Nations General Assembly by Resolution 47/135 of 18-12-1992: adopted the "Declaration on the Rights of Persons belonging to National, Religious and Linguistic Minorities". Article 1 of the Declaration imposes liability on the States to promote and protect the linguistic identity of minorities. It also says that State parties should make legislation in their own State and adopt other measures to promote and protect linguistic identities. In addition, the Convention for the Safeguarding of the Intangible Cultural Heritage, came into existence in 2003 but was ratified on 20 April 2006 when thirty States ratified it. The purpose of the Convention was to safeguard the intangible cultural heritage. The term 'intangible cultural heritage' as used in this Convention includes oral traditions and expressions, including language and the performing arts. The Convention provides that the State parties are supposed to take necessary measures to ensure the safeguarding of the intangible cultural heritage present in its territory. These measures include identification of the intangible cultural heritage that exists in its territory, adoption of appropriate policies, and promotion of education and so on.
Vol. 11 No. 012021

82801101202105

\section{B. National Provisions}

In India there is no special legislation to protect the endangered languages. Being a signatory of the Declaration on the Rights of Persons belonging to National, Religious and Linguistic Minorities, 1992 India was under the obligation to implement it. That is why under the inspiration of this Declaration, the Indian Parliament enacted the National Commission of Minority Act,1992 .However, this Act has focused on religious minorities and did not pay heed on linguistic minorities. For instance, Sindhi being a linguistic minority committee did not get a mention/protection in thus Act and only six religious minority languages have been considered as minority in this Act. These six religious communities are Muslims, Christians, Sikhs, Buddhists, Zoroastrians (Parsis) and Jains. They have been defined in Gazette of India as minority communities by the Union Government. In the Original notification of 1993 only five religious communities Sikhs, Buddhists, Parsis, Christians and Muslims were considered minorities.

Although, the Indian Constitution does not define the word endangered languages and minority it has provided constitutional safeguards and fundamental rights to minorities. Part III of the Indian Constitution makes certain provision regarding protection of minorities to preserve their languages and culture. Article 29 of the Constitution authorizes the linguistic minority citizens of India who are Indian residents to conserve their languages, scripts and culture. Article 29 does not impose any positive obligation on the State to take any action to conserve any culture or language. It merely enables a cultural or linguistic minority people to preserve their own culture or language and bars the State from imposing any other languages on them. Article 29 says that any citizen of India whether he is from a minority community or not, if having distinct language, script or culture are entitled to get the benefit of Article 29(1) of the Constitution. The Sindhi community is not covered under the purview of minority as per the National Commission of Minority Act,1992, although, they have distinct scripts and languages and are entitled to conserve their scripts and languages. It is to be noted that Article 29(1) mentions the word 'conserve' not 'preserve'. The word 'preserve' is passive in nature which means right to maintain its existence. The word 'conserve' is wider than 'preserve'. It is an active right which connotes not only to maintain but also to promote and develop. The term 'conserve' used in this Article does not mean only to preserve but includes the right to follow its own school morals and intellectual way of life. Even the Supreme Court of India in the case of Jagdeo Singh Sindhantiv Pratap Singh Daulta held

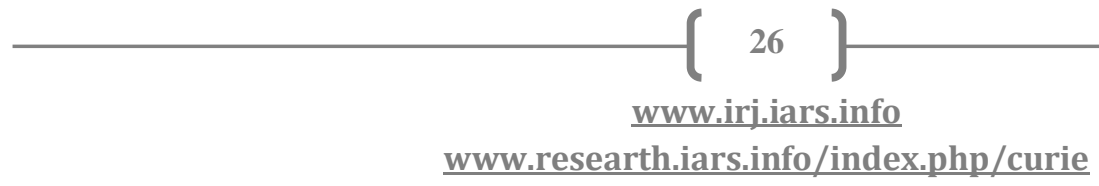




\section{Yimternational Research Journal}

p-ISSN 2202-2821 e-ISSN 1839-6518 (Australian ISSN Agency)

that right to conserve the language of the citizens includes the right to agitate for the protection of the language. Political agitation for conservation of the language of a section of the citizens cannot therefore be regarded as a corrupt practice within the meaning of Section 123(3) of the Representation of the People Act, 1951.

Apart from the above, Article 30(1) gives protection to all linguistic minorities to establish and administer educational institutions of their own choice. This provision also helps to protect scripts and languages as these institutions are free to teach the languages of their own choice. However, this Article helps only those who are declared as a minority. If they are not a declared minority, they can not avail the benefit of Article30(1) of the Constitution. However, the beauty of these two provisions is that they are fundamental rights and if these are infringed the aggrieved person can move to the Supreme Court under Article 32 or to the High Court under Article 226 of the Constitution for enforcement of these rights. As for as the status of a minority is concerned the Supreme Court of India in the case of T.M.A.Pai Foundation $v$ State of Karnataka held that minority status is determined on the basis of the state not taking into consideration the population of the country as whole. In the case of Inre Kerala Education Bill's case the Supreme Court held that the distinct language, script or culture of minority community can be conserved by and through the educational institution. Through education their culture can be inculcated into the mind of children of a community.

In addition, the Eighth Schedule of the Indian Constitution mentions twenty-two languages. It can be said that these languages have achieved linguistic citizenship. These languages have certain benefits for example the Jnanpith award is given to authors who have worked in the languages mentioned in the Eighth Schedule. Moreover, a candidate appearing in an examination conducted by Union Public Service Commission is entitled to use any of these languages in the answers script.

Language is not just a means of communication, but it is a powerful instrument in shaping one's cultural, social and economic identity. Therefore, it is a matter of important concern in children education, the language in which one is imparted education is the reason for good or bad performance of a child in school as language is the only means to ensure the comprehensibility of knowledge by a child. A knowledge imparted in a foreign language not comprehensible to a child cannot form the strong foundation for a good education to a child. After independence, the mother tongue has received special emphasis as a medium of instruction. In order to make
Vol. 11 No. 012021

82801101202105

school education more effective, the law should necessarily address the language issue in such a manner that it enables all children to attend schools and participate meaningfully. An initiative has been taken in this direction and Article 350A has been provided in the Constitution, which makes provision to provide instruction to students in their mother tongue. Article350 A of the Constitution supplements Article29.Inthe case of General Secretary Linguistics Minorities Protection Committee. State of Karnataka the Karnataka High Court stated that Article 45 will be read with Article 350A. The Court said that the Constitution does not empower the State government to thrust the language of the majority as the medium of instruction for primary stage children belonging to linguistic minority groups. Students must be ensured that at their primary stage of education they must be taught in their mother tongue.

The case of State of Karnataka v. Associated Management of English Medium Primary \& Secondary Schools the State Government compulsorily imposed Kannada or one's mother tongue as the medium of instruction at the level of primary education. In this case the petitioners raised issues that it infringes individual's rights to choose their own medium of instruction. The Court said that issuing Kannada or one's mother-tongue in primary education could be considered valid if taken independently, compelling these two as the only options for medium of instruction was seen as unconstitutional. The Court said that the mother-tongue is a language in which the child is comfortable with, and it is up to the parents or guardian of the child to decide their mother tongue. Besides the above, to provide equal opportunities to linguistic minorities for inclusive development and national integration and to spread awareness among the linguistic minorities about the safeguards available to them, the provision of Special Linguistic Officer has been made under 350Bof the Constitution. Article 350B of the Constitution provides for the appointment of a Special Officer for Linguistic Minorities by the President of India. This Officer is known as National Commissioner Linguistic Minorities. He ensures effective implementation of the safeguards provided to linguistic minorities in the constitution and other safeguards agreed to. It shall be the duty of the Commissioner to investigate all matters relating to the safeguards provided for linguistic minorities under this Constitution and report to the President upon those matters at such intervals as the President may direct, and the President shall cause all such reports to be laid before each House of Parliament, and sent to the Governments of the States concerned. Although, the role of Commissioner is creative in nature to safeguard the interests of linguistic minorities, this role is more of an investigating 


\section{Yinternational Research Journal}

p-ISSN 2202-2821 e-ISSN 1839-6518 (Australian ISSN Agency)

nature. He is not directly responsible for implementing or overseeing the progress of implementation and this is the weakness of the present system.

Apart from the above, the Government launched a scheme known as Protection and Preservation of Endangered Languages of India in February 2014. Under this scheme the Central Institute of Indian Languages has been empowered to work on protection, preservation and documentation of all mother tongues of India spoken by less than 10,000 people.

\section{Endangered Languages and the State of Meghalaya}

Meghalaya is the State where there is a matrilineal system. Khasi and Garo with different dialects are the main languages in Meghalaya, however, English is still the major official language of the State. In 2005 the Meghalaya State Language Act, was enacted which received the assent of the Governor on 1st May 2005 and was published in the Gazette of Meghalaya on 4th May 2005. Since its enforcement the English is still Official language of the State. and Khasi \& Garo have been recognized as Associate Official Languages of the State. The Meghalaya State Language Act,2005does not only make Garo and Khasi as Associate Official Language but also protects other languages which are covered under the ambit of linguistic minority.

As for as an Associate Language is concerned the question is if the Constitution permits local languages to be official languages then why is English still an Official Language of the State? The main drawback behind these two languages is that they do not have their own scripts and that is why stillthey are struggling to get a place in the Eighth Schedule. However, Bodo is a language which does not have its own script it has a place in the Eighth Schedule, so the time has come to place Khasi and Garo in the Eighth Schedule. They should also be made official languages of the State in place of the English languageand the English language could be considered as an Associate Official Language.Today in the State of Meghalaya not a single language has been placed in the Eighth Schedule. In my view Khasi \& Garo should be included in the Eighth Schedule so that the speakers of these languages will not be deprived of the benefits which the speakers of languages in the Eighth Schedule are getting.

\section{Conclusion}

There is a diversity of languages in India but many of them are endangered. Although, legal attempts have been made to preserve them these legal attempts are insufficient. Some policies made to preserve endangered languages are not
Vol. 11 No. 012021

82801101202105

properly implemented. The Three language formula should be strictly followed in schools because educational systems play a major role in language choice and language death and revitalization. The mother tongue should be learnt as a second language in schools.

\section{REFERENCES}

[1]. Basu, D.D. Commentary on the Constitution of India, Vol.3, Lexix Nexis, Butterworth, p. 3574. (2008).

[2]. Jain, M.P. Constitutional Law, LexixNexix Butterworth, Nagpur, p.1415. (2008).

\section{Endnotes}

1. Article 27 of the International Covenant on Civil and Political Rights, 1966provides' "In those States in which ethnic, religious or linguistic minorities exist, persons belonging to such minorities shall not be denied the right, in community with the other members of their group, to enjoy their own culture, to profess and practice their own religion, or to use their own language".

2. Article 1 (1) provides; "States shall protect the existence and the national or ethnic, cultural, religious and linguistic identity of minorities within their respective territories and shall encourage conditions for the promotion of that identity".

3. Article1 (2) says; "States shall adopt appropriate legislative and other measures to achieve those ends".

4. Article 1 of the Convention for the Safeguarding of the Intangible Cultural Heritage, 2003

5. Article 2 of the Convention for the Safeguarding of the Intangible Cultural Heritage, 2003

6. Article 11 of the of the Convention for the Safeguarding of the Intangible Cultural Heritage,2003

7. ibid

8. The Act came into force on 17th May,1992

9. Article 29(1) of the Constitution of India says; “ Any section of the citizens residing in the territory of India or any part thereof having a distinct language, script or culture of its own shall have the right to conserve the same"

10. Supra note 2 p. 3564

11.ibid

12. ibid

13. AIR 1965 SC 183

14. Article 30(1) of the Constitution of India states; "All minorities, whether based on religion or language, shall have the right to establish and administer educational institutions of their choice" $i$

15. Article 32(1) of The Constitution of India states, "The right to move the Supreme Court by appropriate proceedings for the enforcement of the rights conferred by this Part is guaranteed".

Article 32(2) of The Constitution of India states, "The Supreme Court shall have power to issue directions or orders or writs, including writs in the nature of habeas corpus, mandamus, 


\section{Yinternational Research Journal}

p-ISSN 2202-2821 e-ISSN 1839-6518 (Australian ISSN Agency)

prohibition, quo warranto and certiorari, whichever may be appropriate, for the enforcement of any of the rights conferred by this Part".

16. Article 226(1) in The Constitution of India states, "Notwithstanding anything in Article 32 every High Court shall have powers, throughout the territories in relation to which it exercise jurisdiction, to issue to any person or authority, including in appropriate cases, any Government, within those territories directions, orders or writs, including writs in the nature of habeas corpus, mandamus, prohibitions, quo warranto and certiorari, or any of them, for the enforcement of any of the rights conferred by Part III and for any other purpose.

17. (2002) 8 SCC481

18. AIR 1958 SC 956

19. Article 350A provides; "It shall be the endeavor of every State and of every local authority within the State to provide adequate facilities for instruction in the mother-tongue at the primary stage of education to children belonging to linguistic minority groups; and the President may issue such directions to any State as he considers necessary or proper for securing the provision of such facilities".

20. AIR 1989 Kant 226

21. (2014) 9 SCC 485

22. Article 350B (1) provides; "There shall be a Special Officer for linguistic minorities to be appointed by the President".

(2) It shall be the duty of the Special Officer to investigate all matters relating to the safeguards provided for linguistic minorities under this Constitution and report to the President upon those matters at such intervals as the President may direct, and the President shall cause all such reports to be laid before each House of Parliament, and sent to the Governments of the States concerned.

23. Special Officer for Linguistic Minorities,https://www.jagranjosh.com, visited on 15-072020 at 7.30 a.m.

24. ibid

25. Supra note $11, \mathrm{p} .1419$

26. Section 3 of the Meghalaya State Language Act,2005 provides; "Without prejudice to the provisions of Articles 343 and the State of 347 of the Constitution of India and the provisions of the Meghalaya. Meghalaya State Legislature (continuance of the English Language) Act, 1980 and subject to ad hereinafter provided, the English language, shall continue to be the official language of the Stare of Meghalaya.

27. [27]Section 4 of the Meghalaya State Language Act,2005 provides Notwithstanding anything contained $\mathrm{m}$ Section 3, the Khasi language may be used as the associate official language for all purposes in the District, Sub-Divisions and Block level offices of the State Government located in the Districts of East Khasi Hills, West Khasi Hills, Jaintia Hills and RiBboi. The Garo Language $\mathrm{m}$ ay he used as associate official language for all purposes in the districts, SubDivisions and Block. Level Offices of East Garo Hills, West
Vol. 11 No. 012021

82801101202105

G am Hills and South Garo Hills: Provided that only the English language shall continue to be used in all civil and Criminal Courts located in the State; Provided, further, that all inter-district official communications shall be in English.

28. Section 5 of the Meghalaya State Language Act,2005

29. Article 345 of the Constitution says; "Subject to the provisions of Article 346 and 347, the Legislature of a State may by law adopt any one or more of the languages in use in the State or Hindi as the language or languages to be used for all or any of the official purposes of that State: Provided that, until the Legislature of the State otherwise provides by law, the English language shall continue to be used for those official purposes within the State for which it was being used immediately before the commencement of this Constitution". 


\section{Manuscript Processing Footprints}

\section{A. Journal Volume/Issue Details}

This manuscript it published in Vol. 11 No. 012021 issue of IARS' International Research Journal (I'IRJ) This is a Peer Reviewed (Refereed) International Journal archived with National Library of Australia. The mentioned Volume/Issue is a special issue of the journal dedicated to Covid19 Pandemic Conditions across globe.

\section{B. Citation}

Singh, Arun Kumar (2021) "LEGAL PROTECTION OF ENDANGERED LANGUAGES IN INDIA WITH REFERENCE TO MEGHALAYA", IARS’ International Research Journal. Vic. Australia, 11(1). Available at: https://researth.iars.info/index.php/curie

\section{Author Declaration}

- The submission has not been previously published, nor is it before another journal for consideration (or an explanation has been provided in Comments to the Editor).

- The submission file is in OpenOffice, Microsoft Word, or RTF document file format.

- Where available, URLs for the references have been provided.

- The text is single-spaced; uses a 12-point font; employs italics, rather than underlining (except with URL addresses); and all illustrations, figures, and tables are placed within the text at the appropriate points, rather than at the end.

- The text adheres to the stylistic and bibliographic requirements outlined in the Author Guidelines.

- All Terms and Conditions about submission and publishing with IARS' International Research Journal on its official site and other sources have been gone through, understood, and accepted.

- With submission, this is declared that the submitter has all rights of the content, and to submit it. Also the submitter affirms that the rights of the submitted content are hereby transferred to IARS' international Research Journal and its parent company/publisher, without objections or conditions.

\section{Last Plagiarism Report}

Settings : similarity of 09 words in a row considered plagiarized.

Originality Assessment

Overall Similarity: $22 \%$

Date: Jan 11, 2021

Statistics: 818 words Plagiarized / 3802 Total words

Remarks: Moderate similarity detected, you better improve the document (if required). Sources

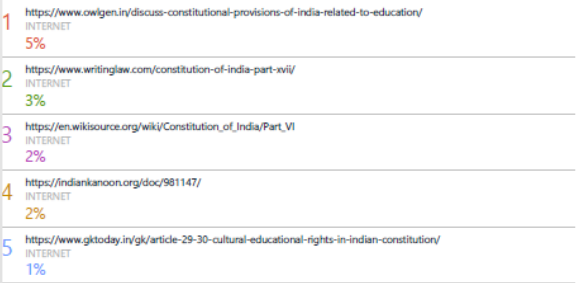

Exemption / Relaxation by Editor: $\quad$ Standard terms and Cited Text (relaxation of 15\%)

\section{E. Processing Track}

\begin{tabular}{|l|l|}
\hline Date of Submission: & 08 November 2020 \\
\hline Date of Referee/Review - 1: & 17 November 2020 \\
\hline Date of Referee/Review - 2: & 17 December 2020 \\
\hline Date of Additional Review: & NA \\
\hline Date of Acceptance: & 11 January 2021 \\
\hline Date of Publishing: & 08 February 2021 \\
\hline
\end{tabular}

